\title{
Low fat goat meat sausage with chitosan-glucose Maillard reaction product: impact on quality and shelf life
}

\author{
Deborah Silva do AMARAL ${ }^{1}$ (D), Alejandra CARDELLE-COBAS ${ }^{2}$, Celina de Castro Querino DIAS ${ }^{1}$, \\ Darlinne Amanda Soares LIMA ${ }^{1}$, Sérgio de Ferreira PEREIRA ${ }^{1}$, Naciza Maria de Oliveira ARCANJO ${ }^{1}$, \\ Paulo Sérgio DALMÁS ${ }^{1}$, Marta Suely MADRUGA ${ }^{1 *}$ (D), Maria Manuela Estevez PINTADO²
}

\begin{abstract}
Low fat fresh goat sausages based on chitosan (LMWC) and derivative chitosan (LMWC-Glc) were developed aiming to produce a functional food product evaluating the effect of inclusion of these compounds on quality, stability and shelf life. Goat sausages ( $10 \%$ pork fat) were formulated with $2 \%(\mathrm{w} / \mathrm{w})$ of LMWC or LMWC-Glc and stored at $4{ }^{\circ} \mathrm{C}$ during 21 days. Results indicated that incorporation of LMWC-Glc and LMWC is technologically feasible, originating a potential functional product with low fat content, besides the positive impact on microbial safety. The modified LMWC (towards better solubility and lower adstringency) incorporated at $2 \%$ as functional ingredient maintained positive effect on antimicrobial, nutrional, textural and sensory performance. The results also proved that derivative chitosan may also be a promising strategy for improving the quality and extending the shelf life of low fat goat sausage.
\end{abstract}

Keywords: chitosan; chitosan-glucose; functional meat product; fat reduction.

Practical Application: Addition of chitosan-glucose in goat sausage to improve quality and increase shelf life.

\section{Introduction}

The goat is known to produce relatively lean meat (Banskalieva et al., 2000), combined with its high digestibility, high protein content, and richness in iron and unsaturated fatty acids, when compared to other red meats (Madruga, 2004). Hence, the best cuts of goat meat are well valorized and sold at high prices, howhever the remaining cuts although still with high nutritional value have low consumer acceptability and no commercial value (Nassu et al., 2003). Therefore, the use of meat from low value goat cuts to produce fresh goat sausages may be an interesting way to valorize the product with very low market acceptability, satisfying the interest of producers and introducing in the market a new meat product (Leite et al., 2015).

Sausages are one of the most popular food product consumed worldwide (Purohit et al., 2016). Howhever, as processed meat product, they have short shelf-life requiring preserving additives to assure safe and good quality products. So, the addition of nitrates and nitrites is permitted (Georgantelis et al., 2007). However, nitrite are involved in the formation of nitrosamines that are known as compounds possibly toxic (Soultos et al., 2008).

In response to recent claims that synthetic antioxidants have the potential to cause toxicological effects and the consumers' increased interest in purchasing natural products, the meat industry has been seeking sources of natural antioxidants (El-Nashi et al., 2015). Among these different natural compounds, chitosan, has attracted especial interest due to possess important functional activities such as antimicrobial, antioxidant, among others (Shahidi et al., 1999), besides be non-toxic, biodegradable and biocompatible (Harish Prashanth \& Tharanathan, 2007).

Previous studies indicated that chitosan possess good potential to increase the stability and shelf-life of pork sausage (Amaral et al., 2015), goat sausage (Amaral et al., 2016) and pork burgers (Sayas-Barberá et al., 2011) among others. However, despite the positive effects it is possible to find in the literature many references on the perception of astringency (Amaral et al., 2015) and little detrimental effects on the textural properties (Chang et al., 2011) in food matrices incorporated with chitosan, besides its low solubility in water (Ruiz Matute et al., 2013). Thus, in order to circumvent these problems it is desirable to modify chitosan, but without affecting its antimicrobial and antioxidant activity (Jiang et al., 2012).

In assessing the synthesis, optimization and structural characterization of a chitosan-glucose derivative obtained by the Maillard reaction Gullón et al. (2016) confirmed the successful introduction of glucose into the chitosan molecule and indicated that the derivative of chitosan can be used in the food industry. However, the application of chitosan-glucose derivative obtained by the Maillard reaction in processed goat meat products or in a range of concentrations enough to reach the health claim was not yet established. Therefore, the objective of this study was to include chitosan (control) and chitosan-glucose complex in a fresh low fat goat sausage in an adequate concentration to be in accordance with EFSA recommendation to support a decrease in 
serum cholesterol ( $3 \mathrm{~g}$ chitosan/day) and establish the effect on the quality, stability and shelf life of the product stored at $4{ }^{\circ} \mathrm{C}$ during 21 days through the evaluation of the microbiological, physico-chemical and sensory parameters (European Food Safety Authority, 2011).

\section{Materials and methods}

\subsection{Sausages ingredients and chitosan}

The goat meat of male animals, not defined breed, slaughtered between 8 and 12 months old, pork fat, ingredients (salt, garlic, onion, powder black pepper, dried oregano, starch and soy protein isolate) and artificial casings were obtained in local markets in the city of Petrolina (Brasil).

Chitosan used in the study was Low Molecular Weight Chitosan (LMWC, Sigma-Aldrich, Steinheim, Germany), previously characterized (Gullón et al., 2016), with a Molecular Weight (MW) of $123 \mathrm{KDa}$ and $90 \%$ deacetylated. The derivative of chitosan (chitosan-glucose Maillard reaction product) obtained by the introduction of glucose was produced using the methodology described in Gullón et al. (2016). Characterization of the derivative chitosan (LMWC-Glc) indicated a MW of $210.37 \mathrm{kDa}$ and a degree of substitution of Glc of $65 \%$, being $25 \%$, the percentage of free amino groups.

\subsection{Sausage preparation}

Three trials were carried out to test the impact of LMWC and LMWC-Glc on quality and shelf life of fresh goat sausages. For this, three lots of low fat sausage ( $10 \%$ pork fat) were manufactured varying the type of chitosan, such as LMWC, LMWC-Glc and a control formulation without chitosan. The base formulation of the sausage was prepared using $75 \%(\mathrm{w} / \mathrm{w})$ of minced goat meat, $10 \%(\mathrm{v} / \mathrm{w})$ of water, $10 \%(\mathrm{w} / \mathrm{w})$ fat, $1.5 \%(\mathrm{w} / \mathrm{w})$ of salt, $0.1 \%(\mathrm{w} / \mathrm{w})$ of powder garlic, $0.2 \%(\mathrm{w} / \mathrm{w})$ of powder onion, $0.1 \%(\mathrm{w} / \mathrm{w})$ of black pepper, $0.05 \%(\mathrm{w} / \mathrm{w})$ of dried oregano, $2 \%$ $(\mathrm{w} / \mathrm{w})$ of starch and $2 \%(\mathrm{w} / \mathrm{w})$ of soy protein isolate. LMWC and LMWC-Glc were added to $2 \%(\mathrm{w} / \mathrm{w})$, being this amount sufficient to accomplish the EFSA specifications for hipocholesterolemic effects of chitosan, assuming the ingestion of $3 \mathrm{~g}$ chitosan/day corresponding to 3 sausages of ca. $50 \mathrm{~g} / \mathrm{each}$.

For the preparation of sausages the minced goat meat was mixed with salt, fat, water and other ingredients (garlic and onion powder, black pepper, starch, oregano, isolated soy protein and chitosan or derivative) in cutter table (JAMAR, model K-10, São Paulo, Brazil). In the case of the derivative LMWC-Glc owing to its soluble character, this was moistened with part of the water to then be added to the formulation assuring better homogenization. Then, the mixture was embedded into artificial casings, using a manual stuffer type cannon (SIEMSEN LTDA, CFMN model ES-08, Brusque, SC, Brazil). The sausages were then placed in plastic bags without vacuum and stored at $4{ }^{\circ} \mathrm{C}$ for up to 21 days. One lot of $1000 \mathrm{~g}$ of fresh goat sausage of each formulation was prepared and two replicates of each sample were analyzed in triplicate on days $0,7,14$ and 21 .

\subsection{Microbiological analysis}

A $8 \mathrm{~g}$ portion from each treatment was homogenized in a Stomacher (Lab Blender 400, London, UK) with $80 \mathrm{~mL}$ of sterile peptone water in plastic bags for two minutes. After was serially diluted in the same diluent and plated in duplicate using the drop method ( $20 \mu \mathrm{L}$ of each dilution), as described by Miles et al. (1938) to evaluate the viable counts of mesophilic and psychrophilic bacteria (plate count agar - PCA, Biokar diagnostics) incubated at $30^{\circ} \mathrm{C}$ for $48 \mathrm{~h}$ and $7^{\circ} \mathrm{C}$ for 7 days, respectively, as well as yeasts and molds (Potato Dextrose Agar - PDA, Biokar diagnostics) being incubated at $25^{\circ} \mathrm{C}$ for 5 days. Enterobacteriaceae were enumerated by the pour-overlay method using Violet Red Bile Glucose Agar (VRBGA, Lab) and the corresponding plates incubated at $37^{\circ} \mathrm{C}$ for $24 \mathrm{~h}$ (International Organization for Standardization, 2004). After incubation, the colonies were enumerated and the colony forming units $(\mathrm{CFU} / \mathrm{mL})$ were calculated. This group of microorganisms were analyzed because usually involve pathogenic and food spoilage.

\subsection{Physicochemical analyses}

Fresh samples

Proximate composition and $\mathrm{pH}$ values

Moisture, ash and protein content of samples were determined at $0,7,14$ and 21 days of storage at $4{ }^{\circ} \mathrm{C}$ by the official AOAC methods of analysis 24.003, 24.009 and 24.027, respectively (Association of Official Analytical Chemists, 1990). Fat content (g fat/100 g sample) was calculated by cold extraction with chloroform/methanol (2:1) by the method of Folch et al. (1957). The $\mathrm{pH}$ values of samples were also measured by a AOAC method of analysis. Specifically they were analyzed by the 943.02 method (Association of Official Analytical Chemists, 2000).

\section{Cooked samples}

Two fresh sausages of each formulation were subjected to cooking to reach $72{ }^{\circ} \mathrm{C}$ at the geometric center after the days 0 , 7,14 and 21 of storage at $4{ }^{\circ} \mathrm{C}$, then were maintained at room temperature until cooling. After cooking, sausages were analyzed.

\section{Moisture and fat retention}

The moisture content were determined before and after cooking. The estimation the amount of moisture retained (Sayas-Barberá et al., 2011) was determined using the following Equation 1:

$\%$ Moisture retention $=100 \times \frac{\text { cooked weight }(g) \times \% \text { moisture in cooked sample }}{\text { raw weight }(g) \times \% \text { moisture in raw sample }}$

\section{Texture Profile Analysis (TPA)}

Four pieces of $1 \mathrm{~cm}$ of each sausage were compressed twice using a texture analyzer (Model TA.XT Plus, Stable Micro Systems, Surrey, England). A cylindrical probe of $6 \mathrm{~mm}$ diameter adaptor with $2 \mathrm{~mm} / \mathrm{s}$ test speed and $70 \%$ compression was used to determine the parameters of hardness, springiness, cohesiveness, gumminess, chewiness and resilience (Lin \& Chao, 2001). 


\subsection{Sensory analysis}

The quantitative descriptive analysis (QDA) was used to evaluate the sensory quality of the goat sausage, using a trained panel of nine members (aged 21-40 years). The triangular tests with goat meat products and commercial sausage, besides basic tastes recognition tests and scaling ability was used at stage to determine the assessors.

The sensory descriptors were defined using the network method (Moskowitz, 1983). The samples were presented in pairs, and each panelist described the characteristics perceived for each attribute as appearance, aroma, flavor and texture. References were determined by a consensus between all assessors, and they were then trained using the identified references for the product attributes (Santos et al., 2015). The training was performed in six sessions, each with three replicates, to evaluate the reproducibility of the assessors.

After the discussion and selection of the descriptors, the samples were evaluated in three repetitions in a monadic form (MacFie et al., 1989), using an unstructured linear scale of $9 \mathrm{~cm}$, with the term "little" at the far left and "far" at the right end of the scale for each descriptor selected (Vidal et al., 2019). For the sensorial analyses, the sausages were grilled in an electrical grill to a core temperature of $72^{\circ} \mathrm{C}$ (Soultos et al., 2008). After cooling for $3 \mathrm{~min}$ at room temperature, the samples were cut into pieces of $3 \mathrm{~cm}$ and served to the assessors in a plastic recipient coded with three-digit number, together with water and biscuit cream cracker to cleanse the palate. Attributes of taste, appearance, flavour and texture were evaluated at days 0 and 7 of storage and at day 14 only the appearance and flavor, to preserve the health of consumers considering the increasing counts of microorganisms, as well as at day 21 the samples already presented unacceptable appearance and flavor.

\subsection{Statistical analysis}

Data were analyzed using the statistical package SAS version 9.4 (2013). The analysis of variance (ANOVA) using the Tukey test was applied to the results of physicochemical, microbiological and sensory analysis to determine the statistically significant differences between formulations during storage. The statistical significance was estimated at $5 \%$ level $(\mathrm{p}<0.05)$ in all cases.

\section{Results and discussion}

\subsection{Microbiological analysis}

The results of microbiological analyses of the fresh goat sausages throughout the 21 days storage period are presented in Table 1 . The counts of all determined microbiological indicators were significantly affected $(\mathrm{p}<0.05)$ by the addition of chitosan and derivative chitosan, as well as, by storage time. In general, the samples treated (with LMWC and LMWC-Glc) had lower microbial counts compared to control sample. Furthermore, it is possible to observe that microbiological counts increased, in all cases as expected, throughout the storage time. In the beginning (day 0) mesophilic bacteria showed levels of of $6.10 \pm 0.05$ and $6.03 \pm 0.10 \log \mathrm{CFU} / \mathrm{g}$ for the sausages with LMWC and LMWC-Glc, respectively, with no statistically difference ( $\mathrm{p}>0.05)$, but higher and signicantly different $(6.28 \pm 0.03)$ for the control sausages. Similar behaviour was found in the counts of moulds and yeasts and Enterobacteriaceae, which showed lower values for the sausages with LMWC and LMWC-Glc than in control sausages. In regarding the psychrophilic bacteria its growth was only reduced by the presence of LMWC $(4.87 \pm 0.10)$, while LMWC-Glc $(5.36 \pm 0.05)$ had no inhibitory effect, showing slightly higher scores than the control sample $(5.15 \pm 0.08)$, at 0 day.

After 21 day of storage at $4^{\circ} \mathrm{C}$ the mesophilic bacteria counts were approximately $0.8 \log \mathrm{CFU} / \mathrm{g}$ lower in the samples treated with $2 \%$ of LMWC and LMWC-Glc, $8.46 \pm 0.04$ and $8.41 \pm 0.05$, respectively, than the control samples, $9.21 \pm 0.08$, $(\mathrm{p}<0.05)$. Counts of moulds and yeasts, psychrophilic and Enterobacteriaceae also increased significantly for all samples $(\mathrm{p}<0.05)$ after 21 days at $4^{\circ} \mathrm{C}$, remaining always lower in samples added LMWC and LMWC-Glc, which promoted a reduction of counts about $0.5 \log \mathrm{CFU} / \mathrm{g}$ compared to the control sausage.

These result is consistent with those reported by other researchers, who demonstrated that the addition of chitosan resulted in antimicrobial effect (Amaral et al., 2015; Georgantelis et al.,

Table 1. Microbial counts (Log CFU/g) obtained for fresh pork sausages with 2\% (w/w) of chitosan (LMWC) and 2\% (w/w) of chitosan-glucose derivative (LMWC-Glc) stored at $4{ }^{\circ} \mathrm{C}$ for 21 days.

\begin{tabular}{lccccc}
\hline \multirow{2}{*}{ Variables } & Treatments & \multicolumn{4}{c}{ Storage period (Days) $^{*}$} \\
\cline { 3 - 6 } & Control & $6.28 \pm 0.03^{\mathrm{dA}}$ & $7.52 \pm 0.02^{\mathrm{cA}}$ & $8.39 \pm 0.03^{\mathrm{bA}}$ & $9.21 \pm 0.08^{\mathrm{aA}}$ \\
\hline Mesophilic & LMWC & $6.10 \pm 0.05^{\mathrm{dB}}$ & $7.03 \pm 0.03^{\mathrm{cC}}$ & $8.13 \pm 0.11^{\mathrm{bB}}$ & $8.46 \pm 0.04^{\mathrm{aB}}$ \\
(log10CFU/g) & LMWC-Glc & $6.03 \pm 0.10^{\mathrm{dB}}$ & $7.22 \pm 0.06^{\mathrm{cB}}$ & $8.28 \pm 0.08^{\mathrm{bA}}$ & $8.41 \pm 0.05^{\mathrm{aB}}$ \\
Psychrotrophic & Control & $5.15 \pm 0.08^{\mathrm{dB}}$ & $5.92 \pm 0.04^{\mathrm{cA}}$ & $7.21 \pm 0.15^{\mathrm{bA}}$ & $7.40 \pm 0.04^{\mathrm{aA}}$ \\
$(\log 10$ CFU/g) & LMWC & $4.87 \pm 0.10^{\mathrm{cC}}$ & $5.65 \pm 0.04^{\mathrm{bB}}$ & $6.75 \pm 0.02^{\mathrm{aB}}$ & $6.82 \pm 0.02^{\mathrm{aB}}$ \\
& LMWC-Glc & $5.36 \pm 0.05^{\mathrm{dA}}$ & $5.75 \pm 0.02^{\mathrm{cB}}$ & $6.72 \pm 0.02^{2^{\mathrm{bB}}}$ & $6.88 \pm 0.04^{\mathrm{aB}}$ \\
Moulds and Yeasts & Control & $6.27 \pm 0.02^{\mathrm{cA}}$ & $7.63 \pm 0.03^{\mathrm{bA}}$ & $9.22 \pm 0.07^{\mathrm{aA}}$ & $9.13 \pm 0.03^{\mathrm{aA}}$ \\
$(\log 10$ CFU/g) & LMWC & $6.03 \pm 0.07^{\mathrm{dB}}$ & $7.30 \pm 0.03^{\mathrm{cC}}$ & $8.33 \pm 0.10^{\mathrm{bB}}$ & $8.79 \pm 0.07^{\mathrm{aB}}$ \\
& LMWC-Glc & $6.11 \pm 0.08^{\mathrm{dB}}$ & $7.42 \pm 0.02^{\mathrm{cB}}$ & $8.43 \pm 0.03^{\mathrm{bB}}$ & $8.55 \pm 0.07^{\mathrm{aC}}$ \\
Enterobacteriaceae & Control & $5.77 \pm 0.02^{\mathrm{dA}}$ & $7.80 \pm 0.04^{\mathrm{cA}}$ & $8.65 \pm 0.11^{\mathrm{bA}}$ & $8.91 \pm 0.03^{\mathrm{aA}}$ \\
$(\log 10$ CFU/g) & LMWC & $5.54 \pm 0.03^{\mathrm{dB}}$ & $7.38 \pm 0.01^{\mathrm{cB}}$ & $8.17 \pm 0.03^{\mathrm{bB}}$ & $8.68 \pm 0.11^{\mathrm{aB}}$ \\
& LMWC-Glc & $5.61 \pm 0.04^{\mathrm{dB}}$ & $7.13 \pm 0.02^{\mathrm{cC}}$ & $8.13 \pm 0.03^{\mathrm{bB}}$ & $8.53 \pm 0.06^{\mathrm{aC}}$ \\
\hline
\end{tabular}

${ }^{\star}$ Different letters $(\mathrm{a}-\mathrm{b})$ in the same row differ significantly $(\mathrm{P}<0.05)$ in time. Different letters $(\mathrm{A}-\mathrm{B})$ in the same column differ significantly $(\mathrm{P}<0.05)$ in samples. 
2007; Sayas-Barberá et al., 2011). Soultos et al.(2008) in fresh pork sausage after 21 days of storage, reported a similar inhibiting effect to our by adding of $1 \%$ chitosan $(0.5 \log \mathrm{CFU} / \mathrm{g})$ for the total viable counts, moulds and yeasts and Enterobacteriaceae, as well as they reported a slightly higher reduction to our (0.9 log CFU/g) for counts of Pseudomonas spp. compared to the control sausage. This inhibitory effect has also been observed for the chitosan-glucose complex. Chang et al. (2011) assessing the antioxidative properties of a chitosan-glucose Maillard reaction product and its effect on pork qualities during refrigerated storage reported a reduction of $1.2 \mathrm{log} \mathrm{CFU} / \mathrm{g}$ for mesophilic bacteria and $2.5 \log \mathrm{CFU} / \mathrm{g}$ of Pseudomonas counts compared to the control sample. Kanatt et al. (2008) reported that the addition of a chitosan-glucose complex in lamb meat had the ability to reduce the number of spoilage organisms and thereby increase the shelf life. Thus, these results confirm that the modification of LMWC did not impact significantly on original antimicrobial activity since the microbiological quality of goat sausages were similar to that obtained with the non-modified LMWC, except for psychrophilic bacteria.

\subsection{Physico-chemical analysis}

\section{Proximate composition and $\mathrm{pH}$}

Table 2 shows the effect of addition of LMWC and LMWC-Glc on the chemical composition and $\mathrm{pH}$ of fresh goat sausages. On day 0 the moisture, protein, fat and ash content were similar to those reported by Amaral et al. (2016) in fresh goat meat sausages manufactured with $12.5 \%$ of fat and added of $2 \%(w / w)$ de chitosan (LMWC). In our study, during storage at $4{ }^{\circ} \mathrm{C}$ the moisture content in fresh goat sausages decreased along the time $(\mathrm{p}<0.05)$, probably due to the loss of water during storage since the casing used was water-permeable according the manufacturer. The loss in moisture content during cold storage of sausage could be referred to moisture vapor migration from the surfaces of sausage samples as a result of difference in water vapor pressure with the surrounding cold air (El-Nashi et al., 2015). Regarding to chitosan and its derivative, the addition promoted a slight decrease in the moisture content when compared with the samples control $(\mathrm{p}<0.05)$. This fact is due to the ability of chitosan to absorb water by hydrogen bonding through its hydroxyl and amine groups (Sormoli et al., 2012).

The results obtained for the protein, fat and ash content were more affected by storage time $(\mathrm{p}<0.05)$ than the chitosans addition on formulation. These parameters during storage increased for all samples, which can be explained by the occurrence of concentration due to the reduction of moisture.

The $\mathrm{pH}$ values were affected $(\mathrm{p}<0.05)$ by chitosan and its derivative, as well as by the storage time. The chitosan and derivative chitosan increased the $\mathrm{pH}$ of the sausages when compared to the control sample (without LMWC), howhever the increase with LMWC-Glc lower, and at day 0 was not significant. This, can be attributed to the basic nature of chitosan (Georgantelis et al., 2007; Sayas-Barberá et al., 2011), promoted by the amino groups present. With respect to storage, the $\mathrm{pH}$ value reduced in all samples, although the reduction with LMWC-Glu was the least. Silva et al. (2014) in cooked goat blood sausage found similar behavior and reported than this indicates the possible development of lactic acid bacteria, however not selective monitored in this study.

\section{Water retention capacity}

The water retention capacity (Table 2 ) of cooking goat sausages was affected by addition of chitosan and by the storage period $(\mathrm{p}<0.05)$. The values for the treated samples with LMWC

Table 2. Proximate composition obtained for fresh goat sausages and water retention capacity (WRC) calculated for cooked goat sausages prepared with $2 \%(\mathrm{w} / \mathrm{w})$ of chitosan (LMWC) and $2 \%(\mathrm{w} / \mathrm{w})$ of chitosan-glucose derivative (LMWC-Glc) stored at $4{ }^{\circ} \mathrm{C}$ for 21 .

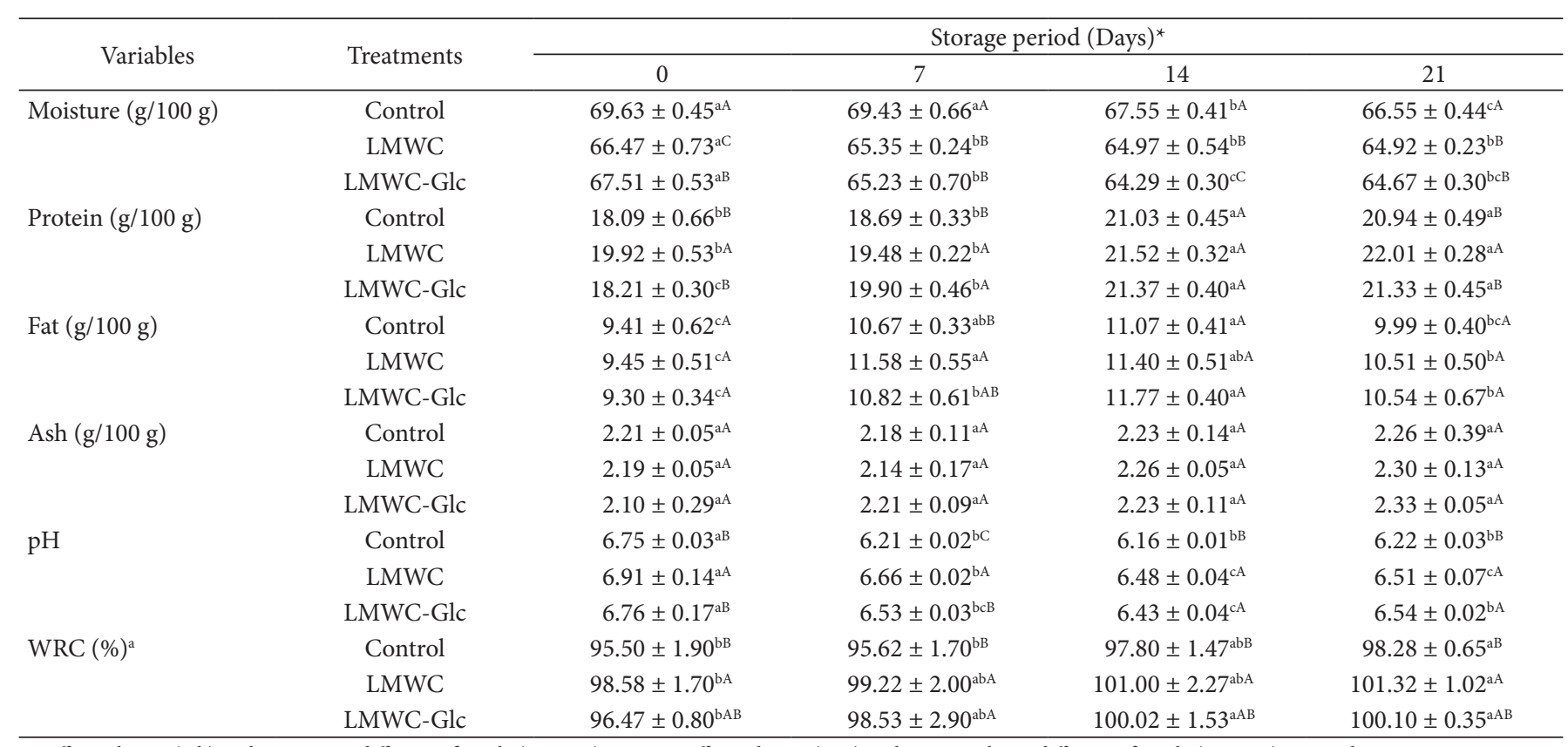

${ }^{*}$ Different letters $(\mathrm{a}-\mathrm{b})$ in the same row differ significantly $(\mathrm{P}<0.05)$ in time. Different letters $(\mathrm{A}-\mathrm{B})$ in the same column differ significantly $(\mathrm{P}<0.05)$ in samples. 
$(98.58 \pm 1.70 \%)$ and LMWC-Glc $(96.47 \pm 0.80 \%)(\mathrm{p}>0.05)$ was higher, at day 0 , than the control samples (95.50 $\pm 1.90 \%)$, but with statistical significance only in the sample added of LMWC when compared with the control sample (without LMWC and LMWC-Glc). This effect is due to water binding ability of chitosan (Sayas-Barberá et al., 2011). After 21 days of storage, water retention capacity increased for all samples, being always greater in the sausages with chitosan (LMWC and LMWC-Glc) than in control sample. Ayadi et al. (2009) reported similar behavior in turkey meat sausages with carrageenan and indicated that with the reduction in $\mathrm{pH}$, the water holding capacity of proteins decreases which leads to an exudation of water outside the product during storage. Therefore, the chitosan and the chitosan derivative by having water retention capacity provide slightly higher yields of the samples.

\section{Texture profile analysis}

The results obtained from cooked goat sausage texture analysis are shown in Figure 1. Between the tested parameters, the hardness is one of more relevant markers and represents the maximum force required to compress the sample (Viana et al., 2003). The hardness of the different formulations increased slightly with the addition of LMWC and LMWC-Glc compared with the control sample (Figure 1a). This increase in hardness can be explained by the fact that chitosan have ability to act as binder, thus favoring the formation of a stronger gel (Kachanechai et al., 2008) promoting a more stable structure.

After 21 days of storage at $4^{\circ} \mathrm{C}$, the hardness of cooked goat sausage increased significantly $(\mathrm{p}<0.05)$, with this increase

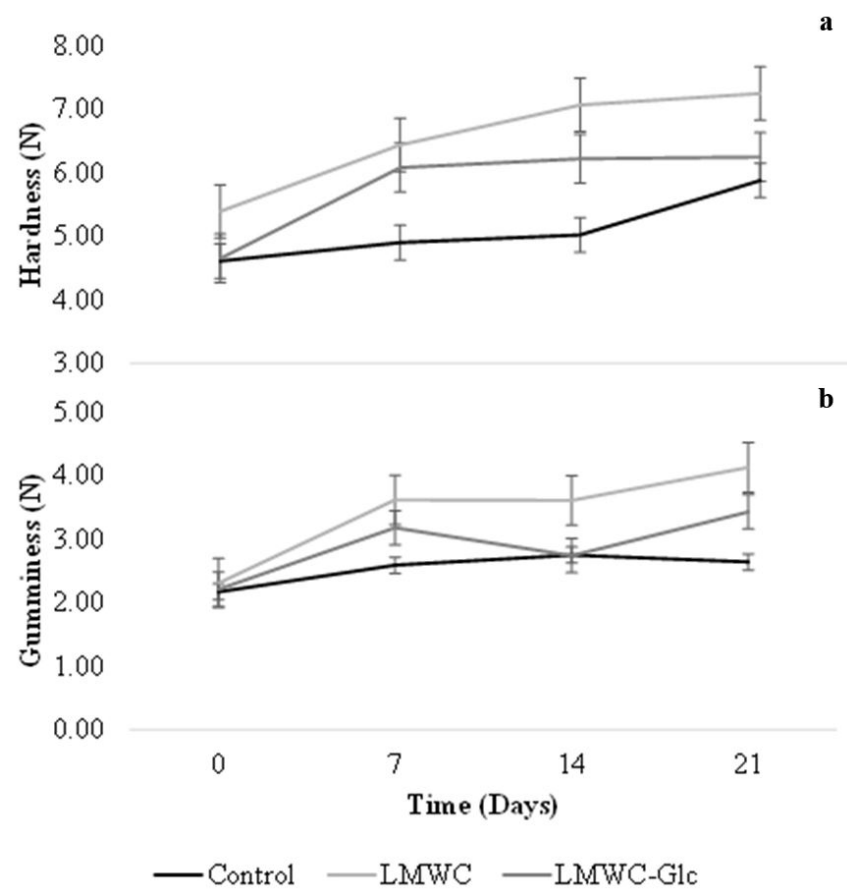

Figure 1. Evaluation of (a) Hardness (N) and (b) Gumminess (N) in fresh goat sausages prepared with $2 \%(\mathrm{w} / \mathrm{w})$ of chitosan (LMWC) and $2 \%(\mathrm{w} / \mathrm{w})$ of chitosan-glucose derivative (LMWC-Glc) stored at $4{ }^{\circ} \mathrm{C}$ for 21 days. being significantly higher in the sausage added of LMWC and LMWC-Glc than in the control sample. These effects can be explained by several factors, such as: loss of water during storage (Andrés et al., 2006), as described before, due to the stabilizations of chitosan linkages with matrix components at refrigerated temperature (Amaral et al., 2016), as well as to protein-protein interaction (Andrés et al., 2006).

The addition of LMWC and LMWC-Glc in sausages also caused an increase in gumminess values (Figure 1b) in relation to control samples. This parameter has direct dependence on result of hardness, thus justifying the similar behavior, increasing with the addition of chitosans and storage time. Gumminess is the force necessary to disintegrate a semi-solid state of the sample until swallowing (Viana et al., 2003). The other textural parameters in general were not affected by the addition of the chitosan and derivative chitosan ( $\mathrm{p}>0.05)$.

\subsection{Sensory analysis}

The results of sensory evaluation of cooked goat sausage are presented in Table 3. In general, all attributes showed a similar behavior, with slight decreasing acceptance $(\mathrm{p}<0.05)$ throughout storage time. On the initial 0 -day of storage, the appearance (visual homogeneity), odor (goat meat), flavour (rancid), texture (softness and juiciness) and overall acceptability scores did not differ significantly between the treatments ( $p>0.05)$. After 14 day of storage at $4^{\circ} \mathrm{C}$ the odor of goat meat significantly reduced irrespective of treatment $(p>0.05)$. Similarly, the scores of appearance reduced over time, but was found lower visual homogeneity in the sample control $(p<0.05)$ than in samples treated with LMWC and LMWC-Glc. This effect can be justified by addition of chitosan, which may allow a sausage with a more stable structure (Amaral et al., 2015). Sayas-Barberá et al. (2011) and Soultos et al. (2008) reported that burgers and fresh pork sausage, respectively, containing chitosan presented the best visual appearance than the control sample.

The rancid flavor after $7 \mathrm{~d}$ of storage increased significantly ( $\mathrm{p}<0.05)$, as expected, being higher in control samples and containing LMWC-Glc than sausage added of LMWC, corroborating the result of TBARS analysis. This result can be explained by the antioxidant activity of chitosan. Similar behavior was reported by Soultos et al. (2008) in fresh pork sausage stored at $4{ }^{\circ} \mathrm{C}$ for $28 \mathrm{~d}$ containing $1 \%$ of chitosan. They indicated that the lower MDA values explain the reduction of rancid flavour, thus causing a more acceptable odour and taste in treated sample than the control samples.

Regarding the texture, LMWC and LMWC-Glc showed positive results, producing higher, numerically, softness and juiciness compared to the control sample, although no significant differences $(\mathrm{p}>0.05)$ were observed between treatments after 7 days of storage. This behavior can be explained by water retention capacity displayed by the chitosan, as described before. Lin \& Chao (2001) in reduced-fat Chinese-style sausage also reported scores slightly higher of juiciness for treatments containing chitosan and demonstrated that this addition resulted in no detrimental effect on textural properties. 
Table 3. Sensory parameters evaluated in cooked goat sausages prepared with $2 \%$ (w/w) of chitosan (LMWC) and $2 \%$ (w/w) of chitosan-glucose derivative (LMWC-Glc) stored at $4{ }^{\circ} \mathrm{C}$ for 21 days using a scale of $9 \mathrm{~cm}$.

\begin{tabular}{|c|c|c|c|c|}
\hline \multirow{2}{*}{ Variables } & \multirow{2}{*}{ Treatments } & \multicolumn{3}{|c|}{ Storage period (Days)* } \\
\hline & & 0 & 7 & 14 \\
\hline \multirow[t]{3}{*}{ Homogeneity } & Control & $6.57 \pm 0.84^{\mathrm{aA}}$ & $6.14 \pm 0.96^{\mathrm{aA}}$ & $5.02 \pm 0.97^{\mathrm{bB}}$ \\
\hline & LMWC & $6.75 \pm 1.35^{\mathrm{aA}}$ & $6.76 \pm 0.98^{\mathrm{aA}}$ & $6.68 \pm 1.31^{\mathrm{aA}}$ \\
\hline & LMWC-Glc & $7.14 \pm 1.09^{\mathrm{aA}}$ & $6.57 \pm 1.72^{\mathrm{aA}}$ & $6.48 \pm 1.98^{\mathrm{aA}}$ \\
\hline \multirow[t]{3}{*}{ Goat meat flavour } & Control & $6.61 \pm 1.16^{\mathrm{aA}}$ & $2.57 \pm 1.00^{\mathrm{bC}}$ & $1.67 \pm 0.84^{\mathrm{bA}}$ \\
\hline & LMWC & $6.81 \pm 1.11^{\mathrm{aA}}$ & $5.80 \pm 1.65^{\mathrm{aA}}$ & $1.88 \pm 1.35^{\mathrm{bA}}$ \\
\hline & LMWC-Glc & $6.41 \pm 1.16^{\mathrm{aA}}$ & $4.39 \pm 1.23^{\mathrm{bB}}$ & $1.73 \pm 0.97^{\mathrm{CA}}$ \\
\hline \multirow[t]{3}{*}{ Rancid flavor } & Control & $0.11 \pm 0.12^{\mathrm{bA}}$ & $0.71 \pm 0.77^{\mathrm{aAB}}$ & ND \\
\hline & LMWC & $0.11 \pm 0.18^{\mathrm{bA}}$ & $0.33 \pm 0.54^{\mathrm{aB}}$ & ND \\
\hline & LMWC-Glc & $0.11 \pm 0.16^{\mathrm{bA}}$ & $0.88 \pm 1.05^{\mathrm{aA}}$ & ND \\
\hline \multirow[t]{3}{*}{ Juiciness } & Control & $5.53 \pm 1.74^{\mathrm{bA}}$ & $5.57 \pm 1.57^{\mathrm{aA}}$ & ND \\
\hline & LMWC & $6.48 \pm 0.83^{\mathrm{aA}}$ & $6.57 \pm 0.64^{\mathrm{aA}}$ & ND \\
\hline & LMWC-Glc & $6.49 \pm 0.59^{\mathrm{aA}}$ & $6.48 \pm 0.81^{\mathrm{aA}}$ & ND \\
\hline \multirow[t]{3}{*}{ Succulence } & Control & $6.19 \pm 1.82^{\mathrm{aA}}$ & $5.90 \pm 2.37^{\mathrm{bA}}$ & ND \\
\hline & LMWC & $6.97 \pm 2.27^{\mathrm{aA}}$ & $6.88 \pm 0.86^{\mathrm{aA}}$ & ND \\
\hline & LMWC-Glc & $7.32 \pm 1.82^{\mathrm{aA}}$ & $6.64 \pm 1.18^{\mathrm{aA}}$ & ND \\
\hline \multirow[t]{3}{*}{ Overall acceptance } & Control & $6.69 \pm 2.06^{\mathrm{aA}}$ & $5.06 \pm 2.32^{\mathrm{aA}}$ & $1.26 \pm 1.40^{\mathrm{bA}}$ \\
\hline & LMWC & $7.02 \pm 2.64^{\mathrm{aA}}$ & $5.33 \pm 2.59^{\mathrm{aA}}$ & $1.61 \pm 1.25^{\mathrm{bA}}$ \\
\hline & LMWC-Glc & $6.06 \pm 3.01^{\mathrm{aA}}$ & $5.59 \pm 2.06^{\mathrm{aA}}$ & $1.40 \pm 1.61^{\mathrm{bA}}$ \\
\hline
\end{tabular}

${ }^{*}$ Different letters $(\mathrm{a}-\mathrm{b})$ in the same row differ significantly $(\mathrm{P}<0.05)$ in time. Different letters $(\mathrm{A}-\mathrm{B})$ in the same column differ significantly $(\mathrm{P}<0.05)$ in samples. ND $=$ not determined.

Finally, the decrease in the overall acceptance after storage for 14 days, observed on all treatments ( $p>0.05$ ), was probably due to the reduction of goat meat odor and increase rancid flavor. Chang et al. (2011), also reported decrease in the overall acceptance and justify with the increased of off-odour on studies to assess the effect of chitosan-glucose Maillard reaction product on pork qualities during refrigerated storage. Thus, confirming the results shown here.

Considering that the use of derivative of chitosan (LMWC-Glc) in the manufacture of fresh goat sausages has been studied for the first time, it is suggested that new investigations are needed, not just in meat products, but also in products of the dairy industry. In relation to sensory profile, methods based in consumer perception and temporal methods can be used to provide better identify the attributes that attract consumers, as well as a better characterization of the products (Esmerino et al., 2017a, b).

\section{Conclusions}

The chitosan and chitosan-glucose maillard reaction product showed similar behavior. However, the derivative of chitosan provided lower hardness than chitosan. In relation to sausages, the results of this study showed that derivative chitosan can also be used effectively to extend the shelf-life of fresh goat sausages stored under chill conditions as previously obtained for chitosan, because was observed reduction of microbial growth in treated samples, when compared with the control sample. Moreover, the fresh goat sausages added with derivative chitosan resulted in best technological quality as observed for chitosan, since it causes an increase in the stability, by ability to bind water and fat, besides a firmer texture, without negative influences on the sensory qualities of the samples. Therefore, although it is necessary to conduct further studies, the use of $2 \%(\mathrm{w} / \mathrm{w})$ chitosan or derivative chitosan, accomplish the requirements of the EFSA, can add value to goat meat allowing to obtain a low fat sausage with improved quality and potential health benefits.

\section{Acknowledgements}

FCT (Fundação para a Ciência e a Tecnologia) through project UID/Multi/50016/2013Pest. D.S. do Amaral thanks PDSE of Coordination for the Improvement of Higher Education Personnel - CAPES, Brazil (BEX 18512-12-7) for a grant under the $\mathrm{PhD}$ program abroad sandwich. A Cardelle-Cobas is grateful to the FCT for the postdoctoral fellowship with reference SFRH/BPD/90069/2012.

\section{References}

Amaral, D. S., Cardelle Cobas, A., Nascimento, B. S., Madruga, M. S., \& Pintado, M. M. E. (2016). Goat sausages containing chitosan towards a healthier product: microbiological, physico-chemical textural evaluation. Food \& Function, 7(9), 4020-4029. http://dx.doi. org/10.1039/C6FO00653A. PMid:27711901.

Amaral, D. S., Cardelle-Cobas, A., Nascimento, B. M., Madruga, M. S., \& Pintado, M. M. (2015). Development of a low fat fresh pork sausage based on Chitosan with health claims: impact on the quality, functionality and shelf-life. Food \& Function, 6(8), 2768-2778. http:// dx.doi.org/10.1039/C5FO00303B. PMid:26158872.

Andrés, S. C., García, M. E., Zaritzky, N. E., \& Califano, A. N. (2006). Storage stability of low-fat chicken sausages. Journal of Food Engineering, 72(4), 311-319. http://dx.doi.org/10.1016/j.jfoodeng.2004.08.043.

Association of Official Analytical Chemists - AOAC. (1990). Official method of analysis (15th ed.). Washington: AOAC.

Association of Official Analytical Chemists - AOAC. (2000). Official methods of analysis. Washington DC. AOAC. 
Ayadi, M. A., Kechaou, A., Makni, I., \& Attia, H. (2009). Influence of carrageenan addition on turkey meat sausages properties. Journal of Food Engineering, 93(3), 278-283. http://dx.doi.org/10.1016/j. jfoodeng.2009.01.033.

Banskalieva, V., Sahlu, T., \& Goetsch, A. L. (2000). Fatty acid composition of goat muscles and fat depots: a review. Small Ruminant Research, 37(3), 255-268. http://dx.doi.org/10.1016/S0921-4488(00)00128-0. PMid:10867324.

Chang, H. L., Chen, Y. C., \& Tan, F. J. (2011). Antioxidative properties of a chitosan-glucose Maillard reaction product and its effect on pork qualities during refrigerated storage. Food Chemistry, 124(2), 589-595. http://dx.doi.org/10.1016/j.foodchem.2010.06.080.

European Food Safety Authority - EFSA. (2011). Panel on Dietetic Products, Nutrition and Allergies (NDA), 2011. Scientific Opinion on the substantiation of health claims related to chitosan and reduction in body weight (ID 679, 1499), maintenance of normal blood LDL-cholesterol concentrations (ID 4663), reduction of intestinal transit time (ID 4664) and reduction of inflammation (ID 1985) pursuant to Article 13(1) of Regulation (EC) No 1924/2006. EFSA Journal, 9(6), 2214.

El-Nashi, H. B., Abdel Fattah, A. F. A. K., Abdel Rahman, N. R., \& Abd El-Razik, M. M. (2015). Quality characteristics of beef sausage containing pomegranate peels during refrigerated storage. Annals of Agricultural Science, 60(2), 403-412. http://dx.doi.org/10.1016/j. aoas.2015.10.002.

Esmerino, E. A., Castura, J. C., Ferraz, J. P., Tavares, E. R. Fo., Silva, R., Cruz, A. G., Freitas, M. Q., \& Bolini, H. M. A. (2017a). Dynamic profiling of different ready-to-drink fermented dairy products: a comparative study using Temporal Check-All-That-Apply (TCATA), Temporal Dominance of Sensations (TDS) and Progressive Profile (PP). Food Research International, 101, 249-258. http://dx.doi. org/10.1016/j.foodres.2017.09.012. PMid:28941691.

Esmerino, E. A., Tavares, E. R. Fo., Thomas Carr, B., Ferraza, J. P., Silva, H. L. A., Pinto, L. P. F., Freitas, M. Q., Cruz, A. G., \& Bolini, H. M. A. (2017b). Consumer-based product characterization using Pivot Profile, Projective Mapping and Check-all-that-apply (CATA): A comparative case with Greek yogurt samples. Food Research International, 99(Pt 1), 375-384. http://dx.doi.org/10.1016/j. foodres.2017.06.001. PMid:28784495.

Folch, J., Less, M., \& Stanley, S. A. (1957). Simple method for the isolation and purification of total lipids from animal tissues. Journal of Biological Chemistry, 226(1), 497-509. PMid:13428781.

Georgantelis, D., Ambrosiadis, I., Katikou, P., Blekas, P., \& Georgakis, S. A. (2007). Effect of rosemary extract, chitosan and $\alpha$-tocopherol on microbiological parameters and lipid oxidation of fresh pork sausages stored at $4^{\circ} \mathrm{C}$. Meat Science, 76(1), 172-181. http://dx.doi. org/10.1016/j.meatsci.2006.10.026. PMid:22064204.

Gullón, B., Montenegro, M. I., Ruiz-Matute, A. I., Cardelle-Cobas, A., Corzo, N., \& Pintado, M. E. (2016). Synthesis, optimization and structural characterization of a chitosan-glucose derivative obtained by the Maillard reaction. Carbohydrate Polymers, 137, 382-389. http://dx.doi.org/10.1016/j.carbpol.2015.10.075. PMid:26686142.

Harish Prashanth, K. V., \& Tharanathan, R. N. (2007). Chitin/chitosan: modifications and their unlimited application potential: an overview. Trends in Food Science \& Technology, 18(3), 117-131. http://dx.doi. org/10.1016/j.tifs.2006.10.022.

International Organization for Standardization - ISO. (2004). ISO 21528 2:2004(E): microbiology of food and animal feeding stuffs: horizontal methods for the detection and enumeration of Enterobacteriaceae. Part 2: colony-count method. Switzerland: ISO.
Jiang, T. J., Feng, L. F., \& Li, J. R. (2012). Changes in microbial and postharvest quality of shiitake mushroom (Lentinus edodes) treated with chitosan-glucose complex coating under cold storage. Food Chemistry, 131(3), 780-786. http://dx.doi.org/10.1016/j. foodchem.2011.08.087.

Kachanechai, T., Jantawat, P., \& Pichyangkura, R. (2008). The influence of chitosan on physicochemical properties of chicken salt-soluble protein gel. Food Hydrocolloids, 22(1), 74-83. http://dx.doi.org/10.1016/j. foodhyd.2007.04.010.

Kanatt, S. R., Chander, R., \& Sharma, A. (2008). Chitosan glucose complex: a novel food preservative. Food Chemistry, 106(2), 521528. http://dx.doi.org/10.1016/j.foodchem.2007.06.036.

Leite, A., Rodrigues, S., Pereira, E., Paulos, K., Oliveira, A. F., Lorenzo, J. M., \& Teixeira, A. (2015). Physicochemical properties, fatty acid profile and sensory characteristics of sheep and goat meat sausages manufactured with different pork fat levels. Meat Science, 105, 114120. http://dx.doi.org/10.1016/j.meatsci.2015.03.015. PMid:25839884.

Lin, K. W., \& Chao, J. Y. (2001). Quality characteristics of reduced-fat Chinese-style sausage as related to chitosan's molecular weight. Meat Science, 59(4), 343-351. http://dx.doi.org/10.1016/S03091740(01)00084-5. PMid:22062958.

MacFie, H. J., Bratchell, N., Greenhoff, K., \& Vallis, L. V. (1989). Designs to balance the effect of order of presentation and first-order carryover effect in halls tests. Journal of Sensory Studies, 4(2), 129-148. http://dx.doi.org/10.1111/j.1745-459X.1989.tb00463.x.

Madruga, M. S. (2004). Qualidade química, sensorial e aromática da carne caprina: verdades e mitos. In Anais do $8^{\circ}$ Encontro Nacional para o Desenvolvimento da Espécie Caprina (pp. 215-234). Jaboticabal: Universidade Estadual Paulista.

Miles, A. A., Misra, S. S., \& Irwin, J. O. (1938). The estimation of the bactericidal power of the blood. The Journal of Hygiene, 38(6), 732749. PMid:20475467.

Moskowitz, H. R. (1983). Product testing and sensory evaluation of foods: marketing and R\&D approaches. Westport: Food and Nutrition Press.

Nassu, R. T., Gonçalves, L. A. G., Silva, M. A. A. P., \& Beserra, F. J. (2003). Oxidative stability of fermented goat meat sausage with different levels of natural antioxidant. Meat Science, 63(1), 43-49. http://dx.doi.org/10.1016/S0309-1740(02)00051-7. PMid:22061984.

Purohit, A. S., Reed, C., \& Mohan, A. (2016). Development and evaluation of quail breakfast sausage. Lebensmittel-Wissenschaft + Technologie, 69, 447-453. http://dx.doi.org/10.1016/j.lwt.2016.01.058.

Ruiz Matute, A. I., Cardelle-Cobas, A., García-Bermejo, A. B., Montilla, A., Olano, A., \& Corzo, N. (2013). Synthesis, characterization and functional properties of galactosylated derivatives of chitosan through amide formation. Food Hydrocolloids, 33(2), 245-255. http://dx.doi. org/10.1016/j.foodhyd.2013.03.016.

Santos, B. A., Bastianello Campagnol, P. C., Cruz, A. G., Galvão, M. T. E. L., Monteiro, R. A., Wagner, R., \& Pollonio, M. A. R. (2015). Check all that apply and free listing to describe the sensory characteristics of low sodium dry fermented sausages: comparison with trained panel. Food Research International, 76(Pt 3), 725-734. http://dx.doi. org/10.1016/j.foodres.2015.06.035. PMid:28455058.

Sayas-Barberá, E., Quesada, J., Sánchez-Zapata, E., Viuda-Martos, M., Fernández-López, F., Pérez-Alvarez, J. A., \& Sendra, E. (2011). Effect of the molecular weight and concentration of chitosan in pork model burgers. Meat Science, 88(4), 740-749. http://dx.doi.org/10.1016/j. meatsci.2011.03.007. PMid:21459523.

Shahidi, F., Arachchi, J. K. V., \& Jeon, Y. J. (1999). Food applications of chitin and chitosans. Trends in Food Science \& Technology, 10(2), 37-51. http://dx.doi.org/10.1016/S0924-2244(99)00017-5. 
Silva, F. A. P., Amaral, D. S., Guerra, I. C. D., Arcanjo, N. M. O., Bezerra, T. K. A., Ferreira, V. C. S., Araújo, I. B. S., Dalmás, P. S., \& Madruga, M. S. (2014). Shelf life of cooked goat blood sausage prepared with the addition of heart and kidney. Meat Science, 97(4), 529-533. http://dx.doi.org/10.1016/j.meatsci.2014.03.018. PMid:24769873.

Sormoli, M. E., Islam, M. I. U., \& Langrish, T. A. G. (2012). The effect of chitosan hydrogen bonding on lactose crystallinity during spray drying. Journal of Food Engineering, 108(4), 541-548. http://dx.doi. org/10.1016/j.jfoodeng.2011.09.011.

Soultos, N., Tzikas, Z., Abrahim, A., Georgantelis, D., \& Ambrosiadis, I. (2008). Chitosan effects on quality properties of Greek style fresh pork sausages. Meat Science, 80(4), 1150-1156. http://dx.doi. org/10.1016/j.meatsci.2008.05.008. PMid:22063850.
Viana, F. R., Silva, V. D. M., Bizzotto, C. S., Laboissière, L. H. E. S., Drumond, M. F. B., Oliveira, A. L., \& Silvestre, M. P. C. (2003). Globina e plasma bovinos, como substitutos de gordura em patê de presunto: efeito da incorporação sobrea composição química, textura e características sensoriais. Alimentos e Nutrição, 14(1), 77-85.

Vidal, V. A. S., Biachi, J. P., Paglarini, C. S., Pinton, M. B., Campagnol, P. C. B., Esmerino, E. A., Cruz, A. G., Morgano, M. A., \& Pollonio, M. A. R. (2019). Reducing 50\% sodium chloride in healthier jerked beef: an efficient design to ensure suitable stability, technological and sensory properties. Meat Science, 152, 49-57. http://dx.doi. org/10.1016/j.meatsci.2019.02.005. PMid:30802818. 